\title{
Islam, Pluralisme dan Kerukunan Hidup Antar Umat Beragama di Indonesia
}

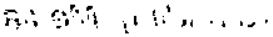

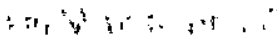

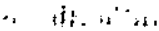

$$
\begin{aligned}
& 13-
\end{aligned}
$$

\section{Pendahuluan}

ndonesia dikenal sebagai suatu sosok masyarakat yang pluralistik yang menyimpan kemajemukan dan keberagamaan dalam hal agama, tradisi, kesenian,kebudayaan, cara hidup dan pandangan nilai yang dianut oleh kelompokkelompok etnis dalam masyarakat Indonesia. Pada suatu sisi, keberagamaan dan kemajemukan ini bagi bangsa Indonesia bisa menjadi sebuah kekuatan yang positif dan konstruktif. Sebaliknya, pada sisi lain, keberagamaan dan kemajemukan ini bagi bangsa Indonesia akan menjadi sebuah kekuatan yang negatif dan destruktif apabila tidak diarahkan secara positif. Situasi semacam ini sangat disadari oleh para pendiri (founding fathers) Republik ini. Itulah sebabnya, para pendiri Republik ini - setelah melalui perdebatan konstitusional yang panjang - tidak mendirikan negara Indonesia menjadi negara agama, tetapi sepakat memilih dan menetapkan Pancasila sebagai dasar dan falsafah negara. Dengan demikian, Indonesia dalam perjalanan sejarahnya terkenal sebagai "negara Pancasila".

Sejauh menyangkut agama, Negara telah meletakkan dasar-dasar konstitusional yang kuat dengan memberikan jaminan dan kebebasan kepada setiap penduduk dan setiap kelompok pemeluk agama untuk menjalankan ibadah dan agamanya menurut keyakinan dan kepercayaannya masingmasing. Hal ini secara jelas dan tegas telah dicantumkan dalam UUD 1945 pasal 29 ayat 1 dan 2 yang berbunyı: "Negara berdasar atas Ketuhanan Yang Maha Esa. Negara menjamin kemerdekaan tiap-tiap penduduk untuk memeluk agamanya masing-masıng dan untuk beribadat menurut agamanya dan kepercayaannya itu".

Dalam pada itu, Pemerintah tidak saja sangat menaruh perhatian terhadap kebebasan beragama di Tanah Air, akan tetapi juga sangat menaruh perhatian dan kepedulian yang sungguh-sungguh terhadap pembinaan kerukunan umat beragama di Indonesia. Perhatian Pemerintah terhadap pembinaan toleransi dan kerukunan umat beragama ini telah menjadi kebijakan nasional yang dimasukkan dalam GBHN (GarisGaris Besar Haluan Negara). GBHN 1993. tetap memberikan perhatian penting terhadap bidang agama dan pembinaan kerukunan umat beragama sebagai salah satu tujuan pembangunan jangka panjang kedua (PJP II). Secara jelas tujuan tersebut diarahkan untuk:

Tercapainya suasana kehidupan beragama dan kepercayaan terhadap Tuhan Yang Maha Esa, yang penuh 
keimanan dan ketakwaan, penuh kerukunan yang dinamis antar dan antara umat beragama dan kepercayaan terhadap Tuhan Yang Maha Esa secara bersama-sama makin memperkuat landasan spiritual, moral dan etik bagi pembanguan nasional, yang tercermin dalam suasana kehidupan yang harmonis, serta dalam kukuhnya persatuan dan kesatuan bangsa selaras dengan penghayatan dan pengamalàn Pancasila. ${ }^{1}$

Tujuan di atas dipertegas kembali dalam Bab IV GBHN 1993 ketika membicarakan secara khusus tentang kebijakan dan sasaran Pembangunan Lima Tahun Keenam. Sasaran pembangunan lima tahun keenam di bidang agama (terkait di dalamnya kerukunan antara umat beragama) dan kepercayaan terhadap Tuhan Yang Maha Esa dinyatakan sebagai berikut:

Penataan kehidupan beragama dan kepercayaan terhadap Tuhan Yang Maha Esa yang harmonis, yang tercermin dalam makin meningkatnya keimanan dan ketakwaan terhadap Tuhan Yang maha Esa, makin meningkatnya kerukunan umat beragama dan penganut kepercayaan terhadap Tuhan Yang Maha Esa, makin meningkatnya peran serta umat dalam pembangunan melalui pendidikan di lingkungan keluarga, di masyarakat dan di sekolah. bersamaan dengan perluasan sarana dan prasarana sesuai dengan kebutuhan untuk menunaikan ibadah masing-masing. ${ }^{2}$

\section{Kerukunan Sebagai Prasyarat Pembangunan}

Berangkat dari tujuan yang telah digariskan dalam GBHN 1993 sebagaimana disebutkan di atas, kita berpendapat bahwa sedikit pun tak dapat disangkal bahwa keharmonisan, toleransi dan kerukunan hidup antar umat beragama di Indonesia merupakan faktor yang sangat penting dan strategis. Tanpa adanya toleransi dan kerukunan hidup, hubungan antar umat beragama akan menjadi rawan dan mudah terganggu, dan gangguan ini akan mengakibatkan terjadinya instabilitas dalam kehidupan sosial politik yang tentunya tidak diinginkan oleh Pemerintah. Kasus yang terjadi di Timor-Timur beberapa bulan yang lalu (akhir tahun 1995) dan disusul kemudian dengan pecahnya kerusuhan di Situbondo baru-baru ini (September 1996) dapat ditunjuk sebagai dua contoh yang masih aktual. Kedua rangkaian kasus itu, sebagaimana diketahui bersama, telah mengakibatkan hubungan antar umat beragama menjadi kurang harmonis. Kasus Timor-Timur telah sempat mengganggu hubungan umat Islam dan umat Katolik, sedang kasus Situbondo mengakibatkan terganggunya hubungan umat Kristen dan umat Islam.

Dalam peristiwa yang pertama (kasus Timor-Timur), antara lain terjadi pembakaran masjid oleh sekelompok umat Katolik, sedang dalam kasus yang kedua (kerusuhan Situbondo) antara lain terjadi pembakaran gereja oleh sekelompok umat Islam. Kita tentu merasa prihatin dengan terjadinya kedua peristiwa tersebut. Tetapi kita juga perlu bersyukur bahwa kedua kasus tadi, dengan mendapat perhatian dan penanganan yang serius dari Pemerintah, telah terselesaikan secara bijak. Kejadian seperti

'Lihat Undang-Undang Dasar, Pedoman Penghayatan dan Pengamalan Pancasila, dan Garis-Garis Besar Haluan Negara (Ketetapan MPR No. I/MPR /1993), (Jakarta: BP-7 Pusat, 1993), hlm. 66.

2lbid., him. 90. 
ini tentunya sama sekali tidak kita inginkan, dan kita berharap kasus-kasus seperti ini tidak akan terulang lagi di masa depan. Kita harus melihat kedua kasus tersebut dengan mata yang jeli, hati yang bening dan pikiran yang jernih. Dengan penglihatan semacam ini, kita akan sampai pada suatu pemahaman bahwa terjadinya kasus-kasus tersebut lebih disebabkan oleh faktor-faktor sosial politik, dan bukan oleh faktor dokrinal. Karena doktrin-doktrin setiap agama, termasuk Islam dan Kristen (Protestan dan Katolik), sama sekali tidak mengajarkan untuk mengusik dan mengganggu, apalagi merusak, kehidupan dan harta benda umat agama lain.

Sebagaimana telah dikatakan di muka, kita sudah barang tentu tidak menginginkan terjadinya (dan terulangnya) kasus-kasus seperti di atas. Dilihat dari perspektif hubungan antar umat beragama yang lebih jauh ke masa depan, barangkali kasus Timor-Timur dan situbondo mengandung hikmah tersembunyi (blessing in disguise). Kedua kasus ini barangkali menyadarkan dan mengajarkan kepada kita semua agar kita lebih bersikap dewasa, lebih toleran dan lebih arif dalam menjalani hidup berdampingan secara damai antar kelompokkelompok umat beragama. Kita diajar untuk lebih mengerti adanya pluralisme agama di Tanah Air kita, yang atas dasar pengertian itu kita saling mengakui dan menghormati hak hidup dan karakteristik kelompok umat beragama yang berbeda-beda. Kita pun diajar untuk lebih memahami secara arif dan bijaksana tentang adanya kemajemukan umat beragama di Tanah Air, dan kemajemukan ini - seperti dikatakan Presiden Soeharto beberapa waktu yang lalu - tidak perlu menjadi penghalang atau kendala bagi seluruh lapisan bangsa Indonesia untuk membina persatuan dan kesatuan bangsa demi terciptanya stabilitas, unitas dan integritas nasional.

\section{Pluralisme agama di Indonesia}

Indonesia dikenal sebagai bangsa yang pluralistik karena ia menyimpan akarakar keberagamaan dalam hal agama, etnis, tradisi, seni budaya dan cara hidup. Sosok keberagamaan yang indah ini, dengan latar belakang mosaik-mosaik yang memiliki nuansa-nuansa khas masing-masing, tidak mengurangi makna kesatuan Indonesia. Motto Nasional "Bhinneka Tunggal Ika" (Unity in diversity) yang dipakai oleh bangsa Indonesia jelas mempertegas pengakuan adanya "kesatuan dalam keragaman atau keragaman dalam kesatuan" dalam seluruh spektrum kehidupan kebangsaan kita.

Pluralitas kehidupan bangsa Indonesia sudah sejak lama menjadi bahan kajian para ahli antropologi, sosiologi dan para pakar lainnya. Hildred Geertz menggambarkan keberagaman kehidupan bangsa indonesia sebagai berikut:

Terdapat lebih dari tiga ratus kelompok etnis yang berbeda-beda di Indonesia, masing-masing kelompok mempunyai identitas budayanya sendiri-sendiri, dan lebih dari dua ratus lima puluh bahasa: yang berbeda-beda dipakai ... hampir semua agama besar dunia diwakili, selain dari agama-agama asli yang

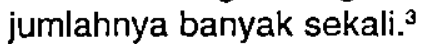

Sejauh menyangkut agama, ada lima agama yang telah diakui secara resmi oleh Pemerintah. Pengakuan resmi ini direalisasikan dalam bentuk teknis pengelolaan kehidupan agama-agama tersebut di bawah Departemen Agama. Kelima agama ter-

${ }^{3}$ Heldred Geertz, "Indonesian Cultures and Communities," dalam Ruth T. McVey (peny.) Indonesia (New Haven: Yale University Press, 1963), 24. 
sebut adalah Islam, Katholik, Protestan, Hindu dan Budha. Departemen Agama atau Pemerintah tentu saja hanya bertugas sebatas mengelola pembinaan kehidupan kegamaan dan umat beragama dari masingmasing agama ini, dan tidak berhak untuk mencampuri urusan akidah dan ibadah dari masing-masing agama tersebut. Karena urusan akidah dan ibadah adalah merupakan urusan intern dari masing-masing agama tersebut.

Dengan demikian, tugas Departemen Agama (Pemerintah) antara lain adalah membina dan memelihara terciptanya toleransi dan. kerukunan hidup antar umat beragama. Pembinaan toleransi dan kerukunan hidup antar umat beragama ini tentu saja bukan hanya merupakan tugas Departemen Agama, akan tetapi juga merupakan tugas semua pihak, terutama masing-masing kelompok dari umat beragama itu. Setiap kelompok umat beragama (termasuk kelompok pemeluk agama yang tidak diakui secara resmi oleh Pemerintah seperti penganut Kong $\mathrm{Hu} \mathrm{Cu}$ dan lain-lain) ikut bertanggungjawab atas terciptanya toleransi dan kerukunan hidup umat beragama di Tanah Air.

\section{Beberapa Pemikiran untuk Mencip- takan Kerukunan Hidup Antar Umat Beragama4}

Sudah sejak lama para ahli ilmu perbandingan agama dan para pemikir keagamaan memikirkan cara-cara untuk menciptakan toleransi dan kerukunan hidup antar umat beragama. Pemikiran ini dipandang sangat penting karena masalah agama, kapan dan di mana pun di dunia ini, adalah merupakan salah satu masalah yang teramat peka dalam kehidupan manusia. Ketersinggungan terhadap sensitivitas emosi keagamaan sudah barang tentu akan menimbulkan terjadinya ketidak- harmonisan dan bahkan konflik yang sengit antar pemeluk agama yang satu dengan pemeluk agama yang lain. Ada beberapa gagasan, cara atau jalan yang dikemukakan oleh para ahli dalam rangka menciptakan toleransi dan kerukunan hidup antar umat beragama. Gagasan-gagasan yang dilontarkan oleh para pemikir di bidang keagamaan dan para ahli perbandingan agama untuk merukunkan antar kelompok-kelompok pemeluk agama dapat dirangkum sebagai berikut.

Pertama, dengan jalan sinkritisme. Paham ini berkeyakinan bahwa'pada dasarnya semua agama itu adalah sama. Sinkritisme berpendapat bahwa semua tindak laku harus dilihat sebagai wujud dan manifestasi dari Keberadaan Asli (zat), sebagai pancaran dari Terang Asli yang satu, sebagai ungkapan dari Substansi yang satu, dan sebagai ombak dari Samudra yang satu. Aliran sinkritisme ini disebut pula Pantheisme, Pan-kosmisme, Universalisme, atau Theo-panisme. Maksud dari istilah-istilah ini adalah bahwa semua (pan) adalah Tuhan dan semua (pan) adalah alam (kosmos). Salah seorang jurubicara sinkritisme yang terkenal di Asıa adalah S. Radhakrishnan, seorang ahli pikir India. 'Jalan sinkritisme yang ditawarkan di atas, menurut Mukti Ali, tidak dapat diterima. Sebab dalam ajaran Islam, misalnya, Khalik (Sang Pencipta) adalah sama sekali berbeda dengan makhluk (yang diciptakan). Antara Khalik dan makhluk harus ada garis batas pemisah, sehingga dengan demikian menjadi jelas siapa yang disembah dan untuk siapa orang itu berbakti dan mengabdi.

${ }^{4}$ Dikutip dan disarikan dari A. Mukti Ali, Kuliah Agama Islam di Sekolah Staf dan Komando Angkatan Udara Lembang (Yogyakarta: Yayasan Nida, 1973), 17 - 24. 
Topik: Islani, Pluralisme dan Kerukunan Hidup, Faisal Ismail

Kedua, dengan jalan rekonsepsi (reconception). Pandangan ini menawarkan pemikiran bahwa orang harus menyelami secara mendalam dan meninjau kembali ajaran-ajaran agamanya sendiri dalam rangka konfrontasinya dengan agama-agama lain. Tokohnya yang terkenal adalah W. E. Hocking, yang berpendapat bahwa semua agama sama saja. Obsesi Hocking yang menonjol adalah bagaimana sebenarnya hubungan antara agama-agama yang terdapat di dunia ini, dan bagaimana dengan cara rekonsepsi tadi dapat terpenuhi rasa kebutuhan akan satu agama dunia. Dengan demikian, kelak akan muncul suatu agama yang mengandung unsur-unsur dari berbagai agama. Misalnya, kandungan itu bisa berupa ajaran kasih sayang dari agama Kristen, pengertian tentang kemuliaan Allah dari agama Islam, perikemanusiaan dari ajaran Kong $\mathrm{Hu} \mathrm{Cu}$ dan perenungan dari agama Hindu. Paham ini menekankan bahwa orang harus tetap menganut agamanya sendiri, akan tetapi ia harus memasukkan unsur-unsur dari agama-agama lain.

Mukti Ali berpendapat, cara kedua ini pun tidak bisa diterima karena dengan menempuh cara itu agama tak ubahnya hanya merupakan produk pemikiran manusia semata. Padahal, agama secara fundamental diyakini sebagai bersumber dari wahyu Tuhan. Bukan akal yang menciptakan atau menghasilkan agama, tetapi agamalah yang memberi petunjuk dan bimbingan kepada manusia untuk menggunakan akal dan nalarnya.

Ketiga, dengan jalan sintesis. Yakni menciptakan suatu agama baru yang elemen-elemennya diambilkan dari agamaagama lain. Dengan cara ini, tiap-tiap pemeluk dari suatu agama merasa bahwa sebagian dari ajaran agamanya telah diambil dan dimasukkan ke dalam agama sintesis tadi. Dengan jalan lain, orang menduga bahwa toleransi dan kerukunan hidup antar umat beragama akan tercipta dan terbina.

Pendekatan dengan menggunakan cara sintesis ini, dalam pandangan Mukti Ali, juga tidak bisa diterima. Agama sintesis itu sendiri tidak bisa diciptakan karena setiap agama memiliki latar belakang historis masing-masing yang tidak secara mudah dapat diputuskan begitu saja. Dengan kata lain, tiap-tiap agama terikat secara kental dan kuat kepada nilai-nilai dan hukum-hukum sejarahnya sendiri.

Keempat, dengan jalan penggantian. Pandangan ini menyatakan bahwa agamanya sendirilah yang benar, sedang agamaagama orang lain adalah salah, seraya berupaya keras agar para pengikut agamaagama lain itu memeluk agamanya. la tidak rela melihat orang-orang lain memeluk agama-agama dan kepercayaan lain yang berbeda dengan agama yang dianutnya. Oleh karena itu. agama-agama lain itu haruslah diganti dengan agama yang ia peluk. Dengan jalan ini ia menduga bahwa kerukunan hidup beragama dapat dicipta dan dikembangkan.

Akan halnya cara keempat ini, Muktı Ali juga tidak dapat menerima karena adanya kenyataan bahwa sosok kehidupan masyarakat itu menurut kodratnya adalah bersifat pluralistik dalam kehidupan agama, ètnis, tràdisi, seni budaya dan cara hidup. Pluralisme kehidupan masyarakat, termasuk dalam kehidupan beragama, sudah menjadi watak dan realitas masyarakat itu sendiri. Cara-cara penggantian sudah pasti tidak akan menimbulkan kerukunan hidup umat beragama, tetapi sebaliknya justru intoleransi dan ketidakrukunan yang akan terjadi. Karena cara-cara tersebut akan mendorong seseorang atau sekelompok orang untuk berupaya keras dengan segala cara (entah cara yang baik atau yang tidak baik) untuk menarik orang-orang lain untuk menganut agama yang dia peluk. 
Kelima, dengan jalan atau pendekatan setuju dalam perbedaan (agree in disagreement). Gagasan ini menekankan bahwa agama yang ia peluk itulah agama yang paling baik. Walaupun demikian ia mengakui, di antara agama yang satu dengan agama-agama lainnya selain terdapat perbedaan juga terdapat persamaan. Pengakuan seperti ini akan membawa kepada suatu pengertian yang baik yang dapat menimbulkan adanya saling harga menghargai dan saling hormat-menghormati antara kelompok pemeluk agama yang satu dengan kélompok penganut agama yang lain.

Dalam visi Mukti Ali, pendekatan yang kelima inilah yang tepat dan cocok untuk dikembangkan dalam membina toleransi dan kerukunan hidup umat beragama, termasuk di Indonesia yang terkenal sebagai masyarakat yang majemuk. Setiap pemeluk agama hendaknya meyakini dan mempercayai kebenaran agama yang dipeluknya itu. Ini adalah suatu sikap yang wajar dan logis. Kalau ia tidak meyakini dan tidak mempercayai kebenaran agama yang dipeluknya itu, ia telah berlaku "bodoh" terhadap agama yang dianutnya itu. Keyakinan akan kebenaran terhadap agama yang dipeluknya ini tidak membuat dia bersikap eksklusif, akan tetapi justru mengakui adanya perbedaan-perbedaan agama yang dianut orang lain di samping - tentu saja - persamaan-persamaan dengan agama yang dipeluknya. Sikap sejerti ini akan membawa kepada terciptanya sikap "setuju dalam perbedaan" yang sangat diperlukan untuk membina dan mengembangkan toleransi dan kerukunan hidup umat beragama di Indonesia.

\section{Islam dan Kerukunan Hidup Umat Beragama}

Menurut bahasa, kata "Islam" berarti tunduk, patuh dan damai. Jadi, karakte- ristik dan watak dasar Islam sebenarnya adalah gagasan komprehensif tentang perlunya perdamaian dalam hidup dan kehidupan manusia. Islam, sebagai agama, diturunkan untuk tujuan mewujudkan kedamaian dan perdamaian. Dengan demikian, segala bentuk terorisme, brutalitas. perusakan dan tindakan kekerasan yang dilakukan oleh kelompok-kelompok Muslim radikal yang mengatasnamakan Islam sebenarnya bertentangan dengan watak dasar dan missi damai Islam itu sendiri. Oleh karena itu, hendaknya perlu dipisahkan antara perilaku orang (orang-orang) Islam dengan Islam sebagai doktrin. Tak ada doktrin dalam Islam (juga dalam agama-agama lain) yang mengajarkan teorisme, brutalitas, perusakan, pembakaran atau pun tindak-tindak kekerasan lainnya.

Islam adalah agama missionary (dakwah), yang menurut kodrat dan wataknya ia harus tersiar dan disiarkan oleh pemeluknya. Dalam menyiarkan islam. Allah SWT dalam Kitab Suci Al-Qur'an tëläh menggariskan tata cara atau metode dakwah yang harus ditempuh oleh umat Islam:

Seluruh (manusia) ke jalan Tuhanmu dengan cara bijaksana dan pelajaran yang baik serta bantahlah mereka dengan cara yang baik (pula). ${ }^{5}$

Sekiranya kamu bersikap keras dan barhati kasar tentunya mereka menjauhkan diri dari sekelilingmu. ${ }^{6}$

Dari firman Allah tersebut di atas, jelaslah upaya-upaya penyiaran Islam oleh umatnya haruslah menempuh cara-cara dakwah yang baik, yaitu dengan cara yang bijaksana, disampaikan dengan cara mem-

5Q.S. an-Nahl: 125 .

${ }^{6}$ Q.S. Ali Imran: 159. 
Topik: Islam, Pluralisme dan Kerukunan Hidup, Faisal Ismail

beri pelajaran yang baik dan dengan cara berdiskusi (berdialog) dengan tata cara yang baik pula. Tidak ada ajaran dalam Islam yang menyuruh pemeluknya untuk menyiarkan Islam dengan cara-cara paksaan dan kekerasan. Sejarah masuknya Islam ke Indonesia juga membuktikan bahwa Islam disiarkan dengan cara persuasif dan damai sebagaimana ditunjukkan oleh cara-cara dakwah yang ditempuh oleh Wali Songo yang menggunakan pendekatan kultural edukatif dalam dakwah mereka. Ini berarti bahwa Islam disiarkan dengan cara-cara persuasif dan tidak dengan caracara radikal konfrontatif, karena Tuhan sendiri melarang untuk menyiarkan Islam dengan cara-cara paksaan dan kekerasan:

Tidak ada paksaan untuk (memasuki) agama (Islam); sesungguhnya telah jelas antara jalan yang benar dan jalan yang salah. ${ }^{7}$

Ungkapan "tidak ada paksaan" yang terdapat dalam ayat al-Qur'an di atas harus diartikan dalam pengertian yang dalam dan luas. Bahwa cara-cara dakwah yang dilakukan oleh umat Islam harus tidak ada motif memaksa, baik itu paksaan secara terang-terangan atau diam-diam, baik itu paksaan secara nyata atau paksaan secara halus dan terselubung. Segala bentuk paksaan dalam penyiaran dan dakwah adalah bertentangan dengan missi suci agama itu sendiri. Setiap bentuk pemaksaan agama (baik dengan cara halus atau terang-terangan) adalah bertentangan dengan prinsip-prinsip hak asasi dan kebebasan beragama yang harus dimiliki oleh setiap manusia. Ketika terjadi "Fathu Makkah" (jatuhnya Mekkah dari tangan kaum Quraisy ke tangan kaum Muslimin), Nabi dan para pengikutnya tidak melakukan tindakan balas dendam dan tidak pula memaksa orang-orang Quraisy untuk memeluk agama islam. Para kepala suku masyarakat Arab di Jazirah Arab berbondong-bondong datang kepada Nabi dengan kesadaran sendiri yang mendalam mereka menyatakan diri memeluk agama Islam.

Prinșip-prinsip kebebasan beragama ini pulalah yang telah dipraktekkan di Madinah oleh Nabi Muhammad ketika dia meletakkan dasar-dasar kerukunan hidup antara umat Islam, komunitas Yahudi dan komunitas non-Muslim lewat Piagam Madinah yang telah disepakati oleh para wakil dari masing-masing kelompók. Piagam Madinah, sebagaimana dikenal dalam sejarah. adalah merupakan suatu piagam politik pertama di dunia yang memuat dasar-dasar toleransi dan kebebasan beragama yang dalam Islam sangat dijunjung tinggi sebagai salah satu hak-hak asasi manusia. Dengan demikian, ide tentang toleransi dan kerukunan hidup antar umat beragama sebenarnya memiliki akar-akar historis yang sangat kuat dalam struktur ajaran Islam dan menemukan bukti-buktinya yang jelas dan nyata dalam praktik-praktik kehidupan Nabi Muhammad SAW. Begitu pula ketika Yerussalem masuk ke dalam kekuasaan Islam, Umar Ibn Khattab (khalifah Rasyidin yang kedua memberikan kebebasan beragama kepada kelompok-kelompok nonMuslim dan membiarkan rumah-rumah lbadah (gereja dan sinagog) tetap berfungsi seperti sediakala. Sebagaimana kita lihat, Yerussalem sekarang ini mempunyai rumah-rumah ibadah dari berbagai agama (Islam, Kristen dan Yahudi) yang diwarisi dari sejarah toleransi umat Islam di masa lampau. Begitu pula, ketika Amru bin ash berhasil menaklukkan negeri Mesir tidak terjadi pemaksaan oleh umat Islam kepada penduduk setempat untuk memeluk agama Islam. Keberadaan komunitas Kopti (yang beragama Kristen) di Mesir dewasa ini

${ }^{7}$ Q.S. al-Baqarah: 256 . 
(yang diperlakukan dengan baik dan adil oleh pemerintah dan rakyat Mesir) adalah merupakan bukti nyata tentang toleransi umat Islam terhadap kelompok minoritas, dan keadaan ini sebenarnya merupakan kesinambungan dari warisan sejarah toleransi umat Islam di masa lampau.

\section{Masalah Kerukunan Hidup antar Umat Beragama di Indonesia}

Masalah toleransi dan kerukunan hidup antar umat beragama di Indonesia sudah sejak awal mendapat perhatian yang serius dari Pemerintah. Pemerintah menyadari bahwa mantapnya toleransi dan kerukunan hidup antar umat beragama adalah merupakan salah satu faktor yang sangat penting dalam membina dan mengembangkan kerukunan nasional. Terciptanya kerukunan nasional sudah barang tentu sangat penting bagi terlaksananya program-program pembangunan nasional. Sebaliknya, ketidakrukunan dan intoleransi antar umat beragama akan mengakibatkan adanya gangguan-gangguan terhadap stabilitas nasional, yang pada gilirannya akan mengganggu jalannya pembangunan nasional.

Salah satu penyebab terjadinya ketidakrukunan antar umat beragama biasanya terkait dengan penyiaran agama yang ditujukan oleh suatu kelompok pemeluk agama Jain. Itulah sebabnya, Menteri Agama Alamsjah Ratu Perwiranegara (sebagai pembantu Presiden yang bertanggung jawab terhadap pembinaan kerukunan hidup antar umat beragama) mengeluarkan Surat Keputusan No. 70/1978 yang berisi pedoman tentang penyiaran agama. Pertimbangan-pertimbangan pokok yang melatarbelakangi dikeluarkannya Surat Keputusan tadi adalah:

(1) Bahwa kerukunan hidup antar umat beragama merupakan syarat mutlak bagi persatuan dan kesatuan bangsa serta kemantapan stabilitas nasional dan keamanan nasional.

(2) Bahwa dalam rangka usaha memantapkan kerukunan hidup antara umat beragama, Pemerintah berkewajiban untuk melindungi setiap usaha pembangunan dan penyiaran agama.

Surat Keputusan Menteri Agama itu mengandung butir-butir pedoman yang cukup komprehensif dan rinci tentang bagaimana suatu agama sebaiknya disiarkan di tengah-tengah masyarakat Indonesia yang pluralistik. Dengan kata lain, Surat Keputusan tersebut mengandung butir-butir etika penyiaran agama yang harus dipegangi dan dipedomani oleh setiap kelompok pemeluk agama dalam menyiarkan agamanya di tengah-tengah masyarakat. Adapun butir-butir pedoman penyiaran agama yang terkandung dalam Surat Keputusan Menteri Agama tersebut adalah sebagai berikut:

(1) Untuk menjaga stabilitas nasional dan demi tegaknya kerukunan hidup antar umat beragama, pengembangan dan penyiaran agama supaya dilaksanakan dengan semangat kerukunan, tenggang rasa, tepo seliro, saling menghargai dan hormat-menghormati antar umat beragama sesuai jiwa Pancasila.

(2) Penyiaran agama tidak dibenarkan untuk:

a. Ditujukan terhadap orang dan atau orang-orang yang telah memeluk sesuatu agama lain.

b. Dilakukan dengan menggunakan bujukan pemberian materiil, uang, pakaian, makanan/minuman, obat-obatan dan lain-lain agar supaya orang tertarik untuk memeluk sesuatu agama.

c. Dilakukan dengan cara-cara penyebaran pamflet, buletin, maja- 
Topik: Islam, Pluralisme dan Kerukunan Hidup, Faisal Ismail

lah, buku-buku dan sebagainya di daerah-daerah/di rumah-rumah kediaman umat/orang yang beragama lain.

d. Dilakukan dengan cara-cara masuk keluar rumah-rumah orang yang telah memeluk agama lain dengan dalih apa pun.

(3) Bilamana ternyata pelaksanaan pengembangan dan penyiaran agama sebagaimana yang dimaksud pada diktum kedua menimbulkan terganggunya kerukunan hidup antar umat beragama akan diambil tindakan sesuai dengan peraturan perundang-undangan yang berlaku.

(4) Seluruh aparat Departemen Agama sampai ke daerah-daerah diperintahkan untuk melakukan pengawasan terhadap pelaksanaan Keputusan ini dan selalu mengadakan konsultasi/koordinasi dengan unsur Pemerintah dan tokoh-tokoh masyarakat setempat.

Keputusan Menteri Agama di atas sudah seharusnya mendapat sambutan dan tanggapan yang positif dari semua pihak. terutama dari para pemuka agama dari masing-masing agama, karena dimaksudkan untuk mencapai tujuan yang baik dan mulia serta luhur dalam rangka membina kerukunan hidup antar umat beragama. Sudah seharusnya pula setiap kelompok agama dengan kesadaran teologis memiliki kewajiban moral dan etis untuk melaksanakan butir-butir pedoman tadi dengan rasa kejujuran dan ketulusan jiwa. Dengan rasa tanggung jawab yang penuh kepada Tuhan, masing-masing kelompok pemeluk agama harus memikul tanggung jawab untuk merealisasikan etika penyiaran agama tadi secara murni dan konsisten. Adalah tidak patut dan tidak pantas rasanya apabila ada seseorang atau sekelompok umat beragama menyalahi atau melanggar butir-butir pedoman etika penyiaran agama yang telah dikeluarkan oleh Pemerintah (Menteri Agama) itu. Saya pribadi menghimbau dan menyerukan agar Surat Keputusan Menteri Agama tentang pedoman penyiaran agama itu ditingkatkan statusnya menjadi Keputusan Presiden (Kepres) agar memiliki kekuatan hukum dan daya efektivitas yang lebih kukuh dan kuat, sehingga dengan demikian pelaksanaan pembinaan kerukunan hidup antar umat beragama akan lebih semakin mantap di Tanah Air.

\section{Pemantapan Kerukunan Antar Umat Beragama}

Dewasa ini seluruh bangsa Indonesia sedang giat-giatnya melaksanakan program-program pembangunan di segala bidang. Keadaan ini sudah pasti memerlukan adanya stabilitas yang dinamis dalam segala bidang, termasuk dalam hubungan antar umat beragama. Intoleransi dan ketidakrukunan antara umat beragama yang satu dengan umat beragama yang lain akan ikut mengakibatkan terjadinya gangguan dan instabilitas dalam kehidupan sosial politik di Tanah Air. Tepat sekali apabila Alamsjah Ratu Perwiranegara (ketika menjabat sebagai Menteri Agama di tahun 1980-an) menyerukan perlunya diciptakan tiga kerukunan, yaitu kerukunan antara umat beragama dengan pemerintah, kerukunan antara umat beragama yang satu dengan umat beragama yang lain, dan kerukunan antar interen pemeluk umat beragama masing-masing. Terciptanya dan terbinanya ketiga kerukunan tadi sudah pasti akan memberikan kontribusi yang besar dan signifikan terhadap lancarnya pelaksanaan pembangunan nasional di Indonesia.

Menteri Agama H. Munawir Sjadzali (pengganti Alamsjah Ratu Perwiranegara) juga menaruh perhatian besar terhadap 
pembinaan kerukunan hidup antar umat beragama. Menurut Munawir, kerukunan hidup antar umat beragama di Indonesia bukan lagi merupakan suatu pilihan, akan tetapi sudah merupakan suatu keharusan. Dalam pandangan Munawir, masuknya agama-agama ke Indonesia berjalan dengan baik sehingga tidak akan menimbulkan hal-hal yang negatif dalam kehidupan bangsa Indonesia secara keseluruhan. Penglihatan ini dikaitkan oleh Munawir kepada tiga faktor. Pertama, semua agama yang masuk ke Indonesia tidak melalui kekerasan militer sehingga tidak ada satu agama pun yang merasa menang atau kalah. Pihak yang kalah biasanya menunggu kesempatan untuk menumbangkan pihak yang menang. Kedua, karena agamaagama yang masuk ke Indonesia ini berlangsung secara damai, maka tidak ada pemutusan batin terhadap kehidupan kultural lama dan oleh karena itu mau tidak mau satu sama lain saling mengakomodasi. Ketiga, temperamen bangsa Indonesia tidak panas. Tidak ada penindasan agama seperti terjadi di Eropa dulu, bahkan agama di Indonesia menjadi motor penggerak revolusi. Agama menjadi faktor yang memenangkan perjuangan bangsa melawan kezaliman penjajah. ${ }^{8}$ Berpegang pada tesis ini, Munawir berlogika bahwa agama-agama di Indonesia yang telah berhasil dijadikan motor penggerak dalam mencapai kemerdekaan bangsa dapat pula dijadikan motor penggerak dalam memacu gerak laju pelaksanaan pembangunan di indonesia. ${ }^{9}$

\section{Penutup}

Bangsa Indonesia telah menikmati masa kemerdekaannya selama 51 tahun. Selama kurun waktu yang cukup panjang ini, kita akui kadang-kadang timbul ketidakharmonisan antara umat Islam dan umat beragama lain (Kristen) seperti tercermin pada kasus Timor-Timur dan kerusuhan Situbondo di atas. Secara jujur kita dapat mengatakan bahwa gangguan-gangguan yang menyebabkan terjadinya ketidakharmonisan antara umat Islam dan umat Kristiani di Indonesia belum serius jika keadannya dibandingkan dengan keadaan yang terjadi antara umat Islam dan Hindu di India atau antara umat Katolik dan Protestan di Irlandia. Serangkaian pembantaian dan pemboman seringkali terjadi di India dan Inggris (yang terakhir ini dilakukan oleh kelompok IRA, Tentara Republik Irlandia) yang menelan korban jiwa yang cukup banyak dan mengerikan. Kita patut bersyukur karena gangguan-gangguan terhadap pembinaan toleransi dan kerukunan hidup antar umat beragama masih relatif kecil dan mudah terkendalikan oleh aparat pemerintah. Di bawah naungan ideologi dan falsafah hidup bangsa, Pancasila, semua umat beragama di Indonesia memikul tanggung jawab untuk mewujudkan töléransi dan kerukunan hidup, dan secara bersamasama berupaya untuk merealisasikan tujuan nasional pembangunan bangsa.

Untuk mencapai tingkat toleransi yang lebih tinggi dan tingkat kerükunan hidup beragama yang lebih harmonis, kiranya dialog-dialog antar umat beragama (yang dasar-dasarnya telah diletakkani oleh Mukti. Ali ketika menjabat sebagai Menteri Agama di tahun 1980-an) perlu terus diintensifkan agar semakin tercipta saling pengertian yang kental dan mendalam. Pengertian yang mendalam dari suatu komunitas agama terhadap karakteristik dan pandangan hidup keagamaan yang dianut oleh suatu komunitas agama yang lain akan memungkinkan kedua kelompok saling harga menghargai dan saling hormat menghormati.

'Lihat Kompas, 24 April 1990.

Ibid. 
Topik: Islam, Pluralisme dan Kerukunan Hidup. Faisal Ismail

Patut pula terus dikembangkan sikap setuju dalam perbedaan (agree in disagreement) di kalangan kelompok-kelompok penganut agama dalam melaksanakan ibadah dan agamanya masing-masing sesuai dengan keyakinan dan kepercayaannya. Keadaan ini, pada gilirannya, akan lebih menumbuhkan suasana harmonis, lebih mengembangkan sikap toleransi dan lebih memantapkan ko-eksistensi damai dan kerukunan hidup antar umat beragama di Indonesia sesuai dengan tujuan yang telah diamanatkan dalam GBHN 1993. Karena kerukunan adalah merupakan salah satu faktor yang sangat penting dan strategis dalam kehidupan bermasyarakat, berbangsa dan bernegara, maka ia akan tetap menjadi muatan fundamental dalam rancangan-rancangan GBHN yang akan datang.

\section{Bibliografi}

Ali, A. Mukti. Dialog antar Agama. Yogyakarta: Yayasan Nida, 1974.

Ali, A. Mukti. Kuliyah Agama Islam di Sekolah Staf dan Komando Angkatan Udara Lembang. Yogyakarta: Yayasan Nida, 1973.

Anorld, T.W. The Preaching of Islam: $A$ History of the Propagation of the Muslim Faith. Lahore: Shir-kat-i Qualam, 1966.
Chitick, William C. "The Theological Roots of Peace and War According to islam," The Islamic Quarterly, XXXIV, 3 (1990): 145 - 163.

Colemen, James J. "Social Cleavage and Religious Conflict," Journal of Social Issue, XII (1956): 44 - 56.

Kelsay, John. Islam and War: A Study in Comparative Ethics. Louisvile: Westminster/John Press, 1993.

Keputusan Menteri Agama No. 79 Tahun 1978 tentang Pedoman Penyiaran Agama.

Majelis Permusyawaratan Rakyat Republik Indonesia. Garis-garis Besar Haluan Negara 1993. Jakarta: BP-7 Pusat, 1996.

McVey, Ruth (ed.) Indonesia. New Haven: Yale University Press, 1963.

al-Qur'an dan Terjemahnya. Jakarta: Proyek Pengadaan Kitab Suci al-Qur'an Departemen Agama Republik Indonesia, 1978.

Rahman, Fazlur, Major Themes of the Qur'an. Chicago: Bibliotheca Islamica, 1991.

Stoddard, L. Dunia Baru Islam. Terj. Muljadi Djojomartono dkk. Jakarta: t.p., 1966.

Watt, W. Montgomery. Muhammad at Mecca. Oxford: Oxford University Press, 1979.

Watt, W. Montgomery. Muhammad at Medina. Oxford: Karachi: Oxford University Press, 1981. 